\title{
Varietal dependent response of barley to soil-borne Waitea circinata infection
}

\author{
Gyula Oros \\ Plant Protection Institute, Hungarian Academy of Sciences, Budapest, Hungary \\ gyoros@aim.com
}

SUMMARY

\begin{abstract}
The disease syndrome caused by Waitea circinata, a soil-borne pathogen introduced in the past decade into Carpathian basin, visually indistinguishable of those caused by various Rhizoctonia strains in diverse host plant. Dicotyledonaceous species in general proved to be more tolerant to this new pathogen than monotyledonaceous ones. This mesophilic fungus can seriously damage cereals. The barley varieties, similarly to other plants, exhibited highly different individual reaction to soil borne infection, Bivoy being the most while Maresi the less tolerant among the 9 tested varieties. Two groups could be separated on the base of their response to Rhizoctonia; Jubilant, Bivoy, Pasadena formed one group being moderately tolerant and Anabell, Scarlett, Rex and Omega the other group of more susceptibles. Three significant factors influence on the virulence of Rhizoctonia strains comprised $62 \%$ of total variation.
\end{abstract}

Keywords: Rhizoctonia, Waitea, barley, susceptibility, soil-borne pathogens

\section{INTRODUCTION}

Traditionally, farmers in temperate zone paid little attention to field damage caused by soil-borne Rhizoctonia infection in cereals, because either seed-borne or air-borne fungi (rust, mildew, smut etc.) infecting stem, leaves and spikelets had been the main constrains of yield. Due to success in breading and arise new synthetic fungicides, these fungi presently do not cause catastrophic yield losses. However, in the last two decades increasing number of papers was published on yield losses (30\% to 70\%) caused by Rhizoctonia species in main cereal cultivating areas (Dorofeyeva et al., 1996; Oros et al., 2013). In South Eastern Hungary damage by the $R$. cerealis and $R$. solani has been observed (Simay, 1998; Kövics and Lörinc, 2001). In August 2002, brown patches were observed on turf grasses in Budapest (Vajna and Oros, 2005). The causative agent associated to $R$. solani was identified as Rhizoctonia zeae Voorhees (teleomorph Waitea circinata Warcup and P.H.B. Talbot) and seemingly is a complex of diverse physiological groups (Ogoshi et al., 2000). This fungus was first found and described on maize in the USA (Vorhees, 1934), than was found in India (Narayanaswamy and Rao, 1984), Japan (Oniki et al., 1985), England (Burton et al., 1988), Alaska (Leiner and Carling, 1994), New Zealand (Christensen, 1996), Turkey (Demirci and Eken, 1999), Iran (Aghajani, 2000), Australia (Lanoiselet et al., 2001) and Brasilia (Poltronieri et al., 2002). R. zeae was associated to R. solani in other samples as well (Sumner and Bell, 1982), By means of comparative studies on more than 150 potential host plants its host range similar to that of $R$. solani (Vajna and Oros, 2005), although the monocotyledonaceous species proved to be less tolerant than dicotyledonaceous ones, contrary to $R$. solani strains.

Both roots and leaves of barley can be infected by Rhizoctonia (Murray, 1982) and coexists as an endophytic fungus frequently without symptoms, however, under unfavorable environmental conditions typical disease syndrome evolves (stunting, wilting, lesions). These typically soil-borne pathogens most frequently cause damping off prevalently in moist and cool conditions that are the main stress factors requested to induce disposition to increased susceptibility of potential host plants (Grogan, 1981). In a comparative study involving 19 wheat varieties, the symptomes caused by $26 R$ solani strains and $R$. zeae were indistinguishable with unarmed eye, and all varieties showed highly variable differences in their individual responses to soil-borne infection in both cases (Oros et al., 2013). Demirci (1998) isolated R. solani on barley and wheat in near the same frequency, however, the abundance of $R$. zeae was 2.5 times more in barley samples. Few data are available of the barley/Waitea interaction (Leiner and Carling, 1994; Demirci, 1998; Paulitz et al., 2003; AlAbdalall, 2010).

Our objectives of this study to make comparative evaluation of responses of germinating barley seeds to Rhizoctonia strains of various origin and taxonomic position as well as to reveal factors influence on barley/Rhizoctonia interaction with special regard to the new Carpathian basin pathogen, $R$. zeae.

\section{MATERIALS AND METHODS}

Greenhouse experiment was undertaken to compare the infectivity of Rhizoctonia zeae strain with seven $R$. solani strains of various origin. Susceptibility of nine barley varieties and fifteen other monocot species were involved in the tests (Table 1). No seed-dressing or any other manners were applied to avoid repression of microbiota in spermosphere. The potting medium was made by mixing forest soil with peat before autoclaving (1.15 atm per 20 mins), at the ratio of 3:1. 


\section{Test Plants}

Seeds of barley varieties (Table 1) were supplied by Dr. A. Tomcsányi (Martonvásár, Hungary), except a local one with unknown genetic background. Triticum monococcum L. cv. Alcor, T. turgidum L. cv. Hegyes were supplied by Elitmag Ltd. (Martonvásár, Hungary), while T. aestivum L. cv. Alcedo was of own propagation. Zea mays L. saccharata cv. Beregi szürke is a local collected variety (Bereg county, East Hungary), and all other seeds were purchased on the market (HERMES Ltd., Budapest, Hungary).

\section{Test Fungi}

The origin of Rhizoctonia strains were from different locations and various hosts. R. zeae B-405 (mixed grass of Festuca and Lolium, Hungary). R. solani strains were isolated in Hungary: B-321 (Solanum tuberosum cv. Ella), B-409 (Hibiscus rosa-chinensis L., imported from Tripoli, Lybia), B-410 (S. tuberosum cv. Kisvárdai rózsa), B411 (S. tuberosum cv. Desirée), B-412 (S. tuberosum cv. Cleopatra), B-413 (Malus domestica L.) and B-433 (Festuca arundinacea Schreb.). The strains were maintained on potato dextrose agar (Merck, Darmstadt, Germany) amended with 2 g soya peptone L44 (Oxoid, Basingstoke, UK).

\section{Test for Pathogenicity}

The sterile potting medium prepared as above was admixed with chickpea seeds previously infested with the pathogen (10 seeds per $250 \mathrm{~g}$ pot), than incubated 96 hours at $26-28^{\circ} \mathrm{C}$ to evolve mycelia. The seeds were put on the surface of infested soil $(1 \times 1 \mathrm{~cm})$, than covered with $5 \mathrm{~mm}$ layer of sterile soil. Sterile distilled water was used to moist the surface ( $15 \mathrm{~mL}$ per pot) and covered with plastic wrap layer to avoid desiccation. The control plants were grown up in Rhizoctonia-free soil.

When the coleoptiles of control plants had been fully developed (8 days after emergence of first germling) the pathological status of all seedlings was evaluated following four fold scale to assess the tolerance of test plants at the 8th days: $0=$ none of seedlings had no visible symptoms by the naked eye; $1=$ most of seedlings were similar to control, but as minimum as one diseased; 2 = the majority of seedlings was dead, but at least one survivor was presented either symptomless or bearing severe symptoms (the coleoptyle and the roots damaged, the root neck scoring); 3 = all seedlings were destroyed. The results of observations were compiled into data matrix $((9$ barley varieties +15 reference plants $) \times$ [1+7] Rhizoctonia strains $)$. The method was discussed in detail previously (Oros et al., 2013).

\section{Data Analysis}

The relationships between host (barley varieties and reference species) and Rhizoctonia strains (potential soil-borne pathogens) have been analyzed by multivariate methods: Potency Mapping (PM) technique and Spectral Component Analysis (Lewi, 2005) combined with Principal Component Analysis (PCA), following a previously described scheme (Magyar and Oros, 2012). In the latter case only the components having an eigenvalue greater than one were included in the evaluation of data to demonstrate potential number of factors remarkably influencing on host-parasite system. The similarity in host spectra of strains was evaluated by Canonic Correlation Analysis (CanCor). Box plot analysis was applied to demonstrate selective differences both in tolerance of test plants and and virulence of Rhizoctonia strains.

Statistical functions of Microsoft Office Excel 2003 (Microsoft, Redmondton, USA) and Statistica5 program (StatSoft 5.0., Tusla, USA) were used for analysis of data. The graphical presentation of result of data analysis was edited uniformly in MS Office Power Point 2003. 
Susceptibility of barley varieties and reference species to soil borne Rhizoctonia infection

\begin{tabular}{|c|c|c|c|c|c|c|c|c|c|}
\hline \multirow{3}{*}{ Test plants } & \multirow{3}{*}{$\begin{array}{c}\text { Rhiz. } \\
\text { zeae } \\
\text { B-405 }\end{array}$} & \multicolumn{8}{|c|}{ Rhizoctonia solani } \\
\hline & & \multirow{2}{*}{$\begin{array}{l}\text { Festuc } \\
\text { B-433 }\end{array}$} & \multirow{2}{*}{$\begin{array}{l}\text { Malus } \\
\text { B-413 }\end{array}$} & \multirow{2}{*}{$\begin{array}{l}\text { Hibisc } \\
\text { B-409 }\end{array}$} & \multicolumn{4}{|c|}{ Potato strains } & \multirow{2}{*}{$\mathrm{PS}^{\mathrm{a}}$} \\
\hline & & & & & B-151 & B-412 & B-410 & B321 & \\
\hline 1. Hordeum vulgare L. ${ }^{\mathrm{b}}$ & 0 & 0 & 0 & 2 & 2 & 2 & 0 & 0 & 0.9 \\
\hline 2. cv. Anabell & 2 & 0 & 1 & 2 & 2 & 1 & 1 & 1 & 1.1 \\
\hline 3. cv. Bivoy & 2 & 0 & 0 & 2 & 2 & 0 & 1 & 1 & 0.9 \\
\hline 4. cv. Jubilant & 2 & 0 & 0 & 3 & 1 & 0 & 0 & 0 & 0.6 \\
\hline 5. cv. Maresi & 2 & 0 & 0 & 2 & 2 & 0 & 0 & 0 & 0.6 \\
\hline 6. cv. Pasadena & 2 & 0 & 0 & 2 & 1 & 0 & 1 & 1 & 0.7 \\
\hline 7. cv. Scarlett & 1 & 0 & 0 & 2 & 1 & 1 & 0 & 0 & 0.6 \\
\hline 8. cv. Rex & 2 & 1 & 1 & 2 & 1 & 0 & 0 & 0 & 0.7 \\
\hline 9. cv. Omega & 1 & 1 & 0 & 2 & 2 & 0 & 0 & 0 & 0.7 \\
\hline 10. Triticum durum Desf. & 1 & 1 & 1 & 3 & 2 & 0 & 1 & 0 & 1.1 \\
\hline 11. T. spelta L. & 0 & 0 & 0 & 1 & 0 & 0 & 0 & 0 & 0.1 \\
\hline 12. T. aestivum L. & 2 & 0 & 0 & 3 & 2 & 2 & 0 & 1 & 1.1 \\
\hline 13. Festuca arundinacea Schreb. & 2 & 1 & 1 & 1 & 1 & 0 & 1 & 0 & 0.7 \\
\hline 14. Festuca rubra L. & 1 & 0 & 0 & 0 & 1 & 0 & 1 & 0 & 0.3 \\
\hline 15. Festuca sp. & 0 & 0 & 0 & 3 & 1 & 0 & 0 & 0 & 0.6 \\
\hline 16. Zea mays L. cornata & 0 & 0 & 0 & 2 & 1 & 1 & 0 & 0 & 0.6 \\
\hline 17. Z. mays L. everta & 0 & 0 & 0 & 2 & 1 & 1 & 0 & 0 & 0.6 \\
\hline 18. Z. mays L. saccharata & 1 & 3 & 3 & 3 & 0 & 1 & 0 & 0 & 1.4 \\
\hline 19. Allium сера L. cv. Owa & 3 & 2 & 2 & 3 & 3 & 1 & 3 & 1 & 1.1 \\
\hline 20. Ä. сера L. cv. Makói bronz & 1 & 0 & 1 & 3 & 3 & 1 & 0 & 0 & 2.1 \\
\hline 21. A. сера L. cv. Makói bronz & 3 & 3 & 3 & 3 & 2 & 2 & 3 & 3 & 2.7 \\
\hline 22. Allium sativus L. & 1 & 1 & 1 & 2 & 2 & 1 & 2 & 2 & 1.6 \\
\hline 23. Allium schoenoprasum L. & 1 & 0 & 0 & 0 & 3 & 0 & 0 & 0 & 0.4 \\
\hline 24. Allium tuberosum Rottler & 3 & 3 & 3 & 3 & 3 & 3 & 3 & 3 & 3.0 \\
\hline PV barley & 1.6 & 0.2 & 0.2 & 2.1 & 1.6 & 0.4 & 0.3 & 0.3 & 0.7 \\
\hline PV Triticum & 1.0 & 0.3 & 0.3 & 2.3 & 1.3 & 0.7 & 0.3 & 0.3 & 0.8 \\
\hline V Festuca & 1.0 & 0.3 & 0.3 & 1.3 & 1.0 & 0.0 & 0.7 & 0.0 & 0.5 \\
\hline PV Zea & 0.3 & 1.0 & 1.0 & 2.3 & 0.7 & 1.0 & 0.0 & 0.0 & 0.9 \\
\hline PV Allium & 2.0 & 1.5 & 1.7 & 2.3 & 2.7 & 1.3 & 1.8 & 1.5 & 1.8 \\
\hline
\end{tabular}

$\mathrm{a}=$ Potential susceptibility of plant to $R$. solani strains, ${ }^{\mathrm{b}}=$ local variety, ${ }^{\mathrm{c}}=$ Potential aggressivity of strains to test plants. Border limits of the scale of evaluation: $0=$ no damage, $1=$ as minimum as one plant injured, $2=$ as minimum as one plant survivied, $3=$ all plants destroyed.

\section{RESULTS}

Responses of host/pathogen pairs

The susceptibility of test plants varied within large limits (Table 1), and low correlation was revealed between responses to $R$. zeae and $R$. solani strains $\left(\mathrm{r}_{\mathrm{wc}, \mathrm{tc}}=0.759, \mathrm{p}=0.028\right)$ by means of multiple correlation. Festuca rubra, Triticum turgidum and a local variety of barley tolerated well both Waitea and Thanatephorus strains, while Allium tuberosum proved to be the most susceptible in both host/parasite systems. In general, barley varieties exhibited medium tolerance to Rhizoctonias with marked selectivity to strains. No differences were observed in symptoms caused in various host/parasite pairs, although there were great alterations in individual responses of seedlings. Stunted growth was the most frequent symptom. The leaf spots occurred in the case of each test plant independently on the longitudinal growth of coleoptiles randomly. No wilted plant was found without root neck decay. Most of $A$. tuberosum seeds were destroyed during the germination, and none of them developed coleoptiles longer than $5 \mathrm{~mm}$ before dumping off. 


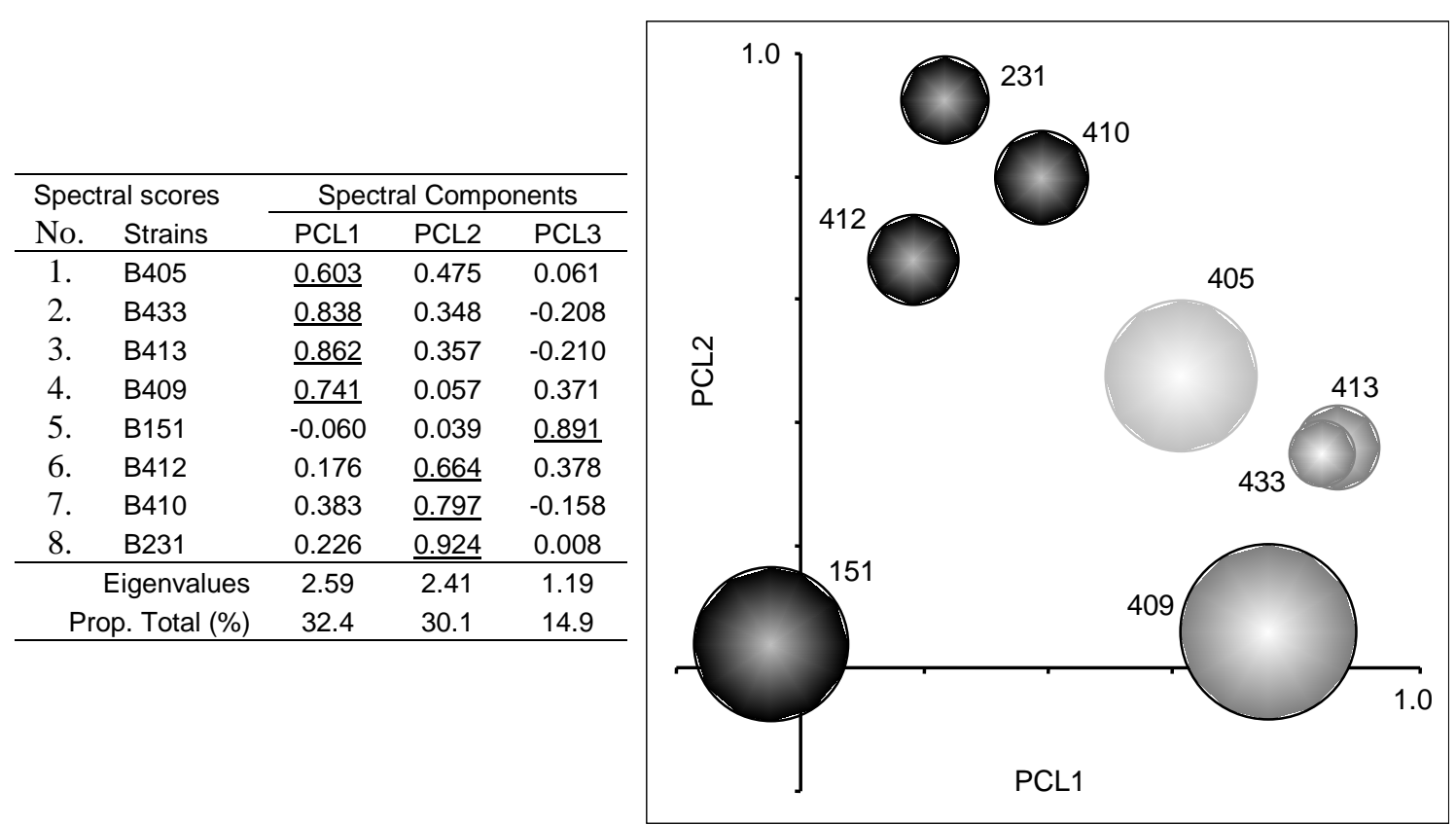

The accession numbers of strains were underlined PC loadings are significantly influencing the component concerned. The distribution of variables on the plot is determined by $62 \%$ of total variation. The grey and black spheres are proportional to overall potential virulence and mark clusters $A$ and $B$ of $R$. solani strains, respectively.

The strains isolated from Hibiscus twig and potato tubers (cv. Desirée) pairing with $R$. zeae were significantly more virulent than the other $R$. solani strains (Table 1), but their host spectrum showed low similarity $\left(\mathrm{r}_{\mathrm{rz}, \mathrm{hib}}=0.34, \mathrm{r}_{\mathrm{rz}, \mathrm{des}}=0.14, \mathrm{r}_{\mathrm{des}, \mathrm{hib}}=0.09<\mathrm{r} 0.1=0.36\right)$. Interestingly, only one of Thanatephorus strains (B151) harmed A. schoenoprasum and Waitea caused significant stunting only.

\section{Factors influence on virulence of Rhizoctonias and plant responses}

The strength of virulence of Rhizoctonia strains was separated by Potency Mapping and their host selectivity analyzed by multivariate techniques (PCA and CanCor). Neither the overall infective potential (Table 1) nor the host range of Rhizoctonia strains were related to their origin (Figure 1). Three components comprised $77 \%$ of total variance of the Spectral Map, where the potato strain (B151) significantly deviated of others that strains clustered into two groups $(A$ and $B$ ) as it was demonstrated on scatterplot (Figure 2). The similarity of host spectrum of $R$. zeae to these groups was significantly different being $R_{405, \mathrm{~A}}=0.54>R_{405, \mathrm{~B}}=0.70$. The origin of strains seemingly did not take role in their host spectrum that was for example, similar $\left(\mathrm{r}_{433,413}=0.94\right)$ of strains originated of Festuca roots and apple cambium.

\section{Factors influencing on plant responses to soil-borne Rhizoctonia infection}

The potential susceptibility of test plant was separated by Potency Mapping. The strength of response to Rhizoctonias varied within large limits (Figure 2), and there was not revealed relationship between taxonomic position and overall potential susceptibility. Although some plants $(1,11,15,16,17)$ proved to be tolerant to $R$. zeae, all others but garlic and sweet corn exhibited higher potential susceptibility to this new pathogen than to $R$. solani strains (Figure 2).

The relationship between test plants and their host spectra was evaluated applying Cluster Analysis (unweighted pair group averages) based on Pearson's correlation matrix of Spectral Map (Figure 2). The plants formed five groups with two outliers $(18,20)$, where barley varieties distributed within four clusters. Seemingly, both response of host and virulence of pathogens are influenced by complex interaction of diverse factors. 
Figure 2: Potential susceptibility of monocotyledonaceous species to soil borne Rhizoctonia infection and their relationships in host specificity

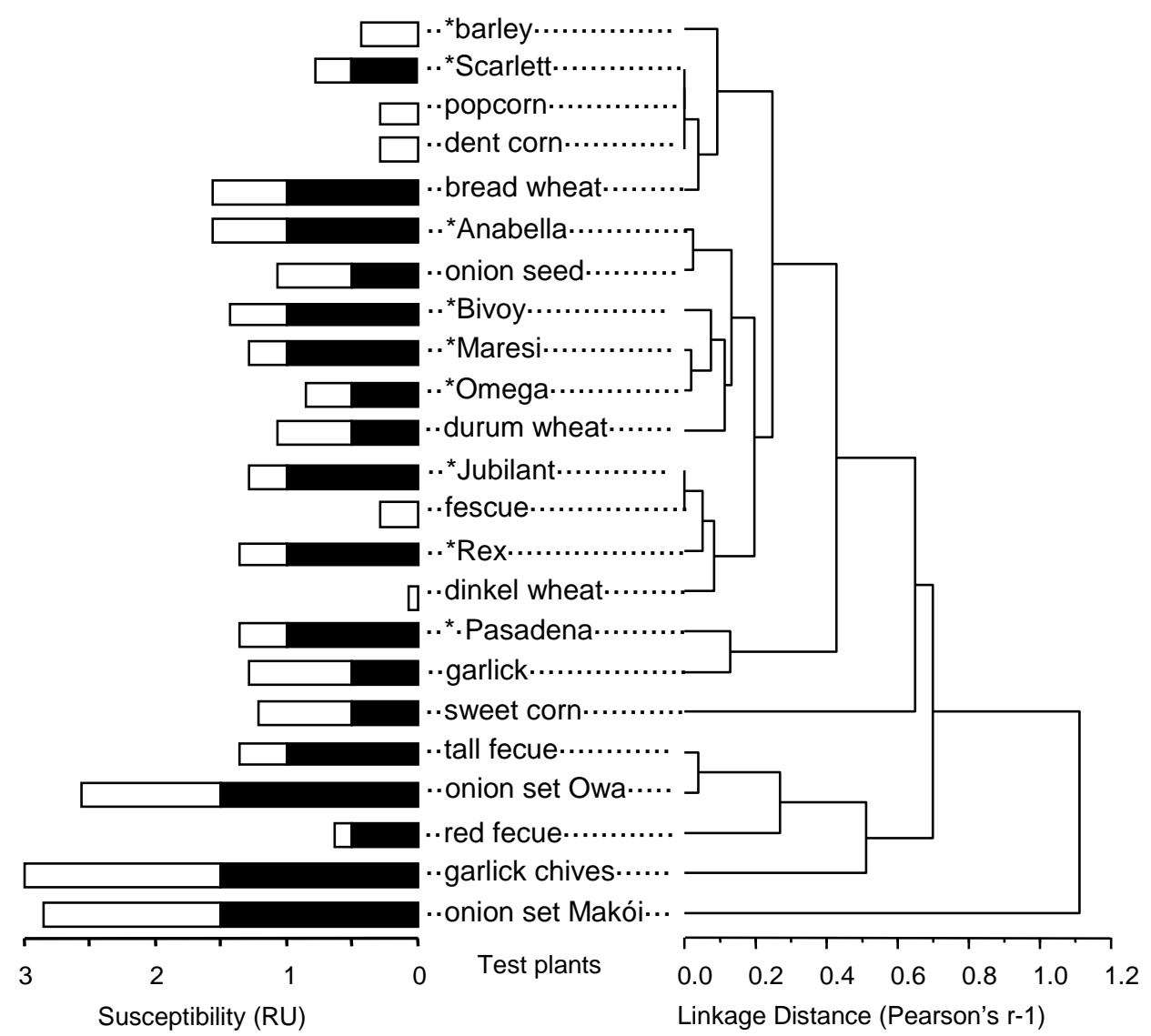

The bold and opened prism on the left graph are proportional to potential susceptibility to soil-borne Waitea circinata and Thanatephorus cucumeris strains. The clusterogram on the right side was calculated of Spectral Map derived of Table 1 according to Lewi (1976). The asterisk $(*)$ labelled plants are barley varieties.

\section{DISCUSSION}

The gene center of barley was most probably in Levant (Gyulai, 2004), and nowadays the most diverse group of Rhizoctonias was found in this area: strains of five anastomosis groups of Thanatephorus cucumeris and two pathotypes of W. circinata were isolated of barley in East Turkey (Demirci, 1998). These two fungi occurred frequently together, and different types are infecting in consortium (Roget et al., 1996; Yamauchi et al., 2002). Nevertheless, their ecological requirements seem to be different, as $R$. zeae was not affected tillage methods contrary to $R$. solani (Schroeder and Paulitz, 2008). The virulence of new for Carpathian basin soil-borne pathogen, $W$. circinata was demonstrated in this study to be almost the most virulent $R$. solani strains tested on barley varieties. Similar results were found with set of strains used in this study with okra (Bittsánszky et al., 2012), ricinus (Bittsánszky et al., 2015) and wheat varieties (Oros et al., 2013). R. solani strains divided into two groups having different host range within monocot plants, and the host range of $R$. zeae strain studied showed significantly similar pattern to one of them.

The elucidation of physiological background of host/Rhizoctonia needs further studies as well as use of experimental models mimicking the field conditions. More attention should be also paid to interaction among associated Rhizoctonia strains residing in the field (Yamauchi et al., 2002). The R. zeae (B405) strain antagonized the associated $R$. solani strain (B433) in brown patches of Festuca/Lolium turf (Figure 3), and it was found in microscopic studies to parasite some other strains as well. However, this parasitic action was strain specific, and there was not revealed relationship between virulence of $R$. solani strains and their susceptibility to $R$. zeae. The strain specific toxin production may take place in determination of virulence and antagonism (Oros et al., 2014), where the acceptor's reaction might be specific as well. 
Figure 3: Strain specific interaction between $R$. zeae and $R$. solani

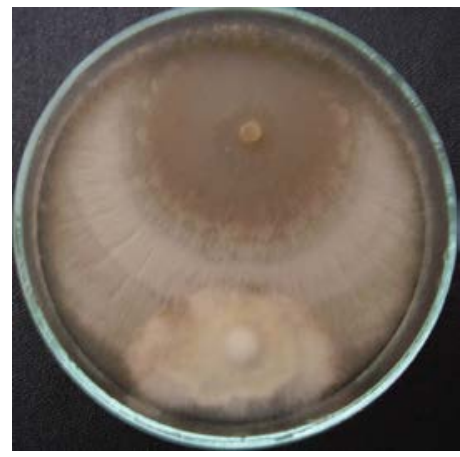

R. zeae vs B151

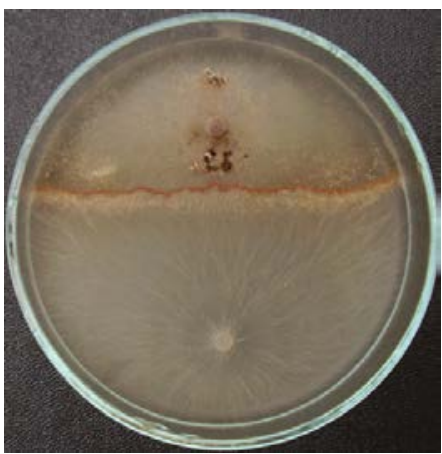

R. zeae vs $\mathrm{B} 433$

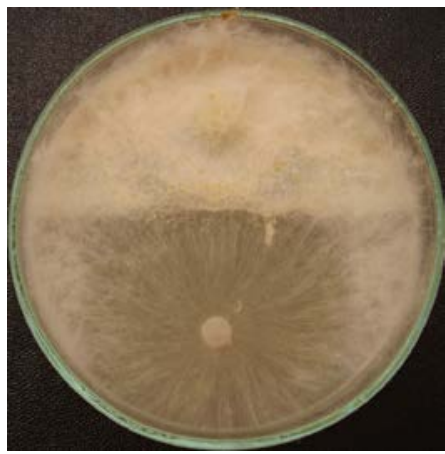

R. zeae vs B409

Five days old cultures are shown on Potato Dextrose Agar

Some efforts have been done to utilize the mycoparasitic property of $W$. circinata in control of several common root diseases (Webb et al., 2015). This initiative underlines the importance of the use of more complex experimental models, as testing only one cultivar of plant to be protected does not result supportive data for application of any preparation in large scale, due to highly varietal selective response of cultivated plants to $W$. circinata infection as well as strain-selective interaction between fungi, thus there is no surety to positive outcome of the application of $W$. circinata based mycopreparate.

\section{CONCLUSIONS}

No relationship was found between taxonomic position and origin of Rhizoctonia strains, indicating that traits used for their classification are not closely related to the expression of their pathogenicity against barley cultivars and other test plants.

Three factors were revealed that significantly affect the host range and virulence of strains in barley/Rhizoctonia system, and only limited overlapping was revealed between $R$. zeae and $R$. solani strains.

We have got empirical evidence from plant/pathogen system on the possibility of selection; the barley phenotype resistant to $R$. zeae and one pathotype of $R$. solani.

\section{ACKNOWLEDGEMENTS}

This study was supported by The National Office for Research and Technology, Grant No. K67688

\section{REFERENCES}

Aghajani, M.A. (2000): Identification of Rhizoctonia and Rhizoctonia-like fungi on poaceae in central region of Mazandaran, M.S. Thesis, Tarbiat Modarres University, Tehran, IR.

Al-Abdalall, Amira Hassan Abdullah (2010): Assessment of yield loss caused by root rots in wheat and barley. Journal of Food Agriculture \& Environment 8, 638-641.

Bittsánszky, A. - Rai, R.V. - Oros, G. (2012): Response of glutathion conjugation system to soil borne Rhizoctonia infection of okra. Acta Phytopathologica et Entomologica 47, 191-202.

Bittsánszky, A. - Deepak, S.A. - Oros, G. (2015): Selective response of Ricinus communis seedlings to soil borne Rhizoctonia infection. Ecocycles 1, 33-38.

Burton, R.J. - Coleysmith, J.R. - Wareing, P.W. - Gladders, P. (1988): Rhizoctonia oryzae and R. solani Associated with Barley Stunt Disease in The United-Kingdom. Transactions of The British Mycological Society 91, 409-417.

Christensen, M.J. (1996): Antifungal activity in grasses infected with Acremonium and Epichloe endophytes. Australasian Plant Pathology 25, 186-191.

Dean, R. - Van Kan, J.A.L. - Pretorius, Y.A. - Hammond-Kosack, K.E. - Di Pietro, A. - Spanu, P.D. - Rudd, J.J. - Dickman, M. - Kahmann, R. - Ellis, J. - Foster, G.D. (2012): The Top 10 Fungal Pathogens in Molecular Plant Pathology. Molecular Plant Pathology 13, 414-430.

Demirci, E. (1998): Rhizoctonia Species and Anastomosis Groups Isolated from Barley and Wheat in Erzurum, Turkey. Plant Pathology $47,10-15$.

Dorofeyeva, L.L. - Tytova, K.D. - Pavlova, V.V. - Syzova, T.P. (1996): Cereals' rhizoctonias. Mikologiya I Fitopatologiya 30, $52-55$.

Grogan, R.G. (1981): The Science and Art of Plant Disease Diagnosis. Annual Review of Plant Pathology 19, 333-351.

Gyulai F. (2004): Distribution and history of the cultivation of barley. In: The Barley (eds. Tomcsányi A. and Turcsányi G.), Akadémia Kiadó, Budapest, pp. 53-79. (in Hungarian)

Kövics, G.J. - Lörincz N. (2001): Causal Agents of Stem-Base Diseases of Winter Wheat in Eastern Hungary. In: Proceedings of Conference, Resources of the Environment and Sustained Development, Oradea, 24-26 May 2001, Analele Universitátii din Oradea. Tom. VII. Scientific Communication Session: Partea I-a. Fascicula Agri-cultură-Horticultura, pp. 37-44. 
Lanoiselet, V.M. - Ash, G.J. - Cother, E.J. - Priest, M.J. - Watson, A. (2001): First report on Waitea circinata causing sheath spot and Rhizoctonia oryzae-sativae causing aggregate sheath spot on rice in Southern-Australia. Australian Plant Pathology 30, 369-370.

Leiner, R.H. - Carling, D.E. (1994): Characterization of Waitea circinata (Rhizoctonia) isolated from agricultural soils in Alaska. Plant Disease 78, 385-388.

Lewi, P.J. (2005): Spectral Mapping, a Personal and Historical Account of an Adventure in Multivariate Data Analysis. Chemometrics and Intelligent Laboratory Systems 77, 215-223.

Magyar, D. - Oros, G. (2012): Application of the Principal Component Analysis to Disclose Factors Influencing on the Composition of Fungal Consortia Deteriorating Remained Fruit Stalks on Sour Cherry Tree. In: P. Sanguansat, Ed., Principal Component Analysis, InTech, Rijeka, pp. 89-110.

Martin, S.B. - Lucas, L.T. (1983): Pathogenicity of Rhizoctonia zeae on tall fescue and other turfgrasses. Plant Disease 67, 676-678.

Murray, D.I.L. (1982): Penetration of Barley Root and Coleoptile Surfaces by Rhizoctonia solani. Transactions of The British Mycological Society 79, 354-360.

Narayanaswamy, T. - Rao, A.V. (1984): Waitea circinata - A New Fungus Causing Sheath Blight on Rice. Current Science, 53, 874-874.

Ogoshi, A. - Cook, R.J. - Bassett, E.N. (1990): Rhizoctonia species and anastomosis groups causing root rot of wheat and barley in the Pacific Northwest. Phytopathology 80, 784-788.

Oniki, M.O. - Araki, A. - Sakai, T. - Tanaka, R.S. (1985): The perfect state of Rhizoctonia oryzae and Rhizoctonia zeae, and the anastomosis groups of Waitea circinata. Transactions of The Mycological Society of Japan 26, 189-198.

Oros, G. - Bittsánszky, A. - Pilinszky, K (2014): Response of Arabidopsis clones to toxic compounds released by various Rhizoctonia species. American Journal of Plant Sciences 5(3):364-371.

Oros, G. (2004): Rhizoctonia Species. Gaps to Be Filled in the Hungarian Soil Science. Tiszántúli Növényvédelmi Fórum Elöadásai, Debrecen, 18-20 October 2004, pp. 321-329.

Oros, G.- Naár, Z. - Magyar, D. (2013): Susceptibility of wheat varieties to soil-borne Rhizoctonia infection. American Journal of Plant Sciences 4, 2240-2258.

Paulitz, T.C. - Smith, J.D. - Kidwell K. K. (2003): Virulence of Rhizoctonia oryzae on wheat and barley cultivars from the Pacific Northwest. Plant Disease 87, 51-55.

Poltronieri, L.S. - Trinidade, D.R. - Albuquerque, F.C. (2002): Rot of corn caused by Rhizoctonia zeae in the state of Pará, Brazil. Fitopatologia Brasilera 27, 423-423.

Roget, D.K. - Neate, S.M. - Rovira, A.D. (1996): Effect of Sowing Point Design and Tillage Practice on the Incidence of Rhizoctonia Root Rot, Take-All and Cereal Cyst Nematode in Wheat and Barley. Australian Journal of Experimental Agriculture 36, 683-693.

Schroeder, K.L. - Paulitz, T.C. (2008): Effect of inoculum density and soil tillage on the development and severity of Rhizoctonia root rot. Phytopathology 98, 304-314.

Simay, E.I. (1998): Outbreak of Rhizoctonia solani Kühn on oat (Avena sativa) in Hungary. Cereal Research Communications 17, 233-235.

Sumner, D.R. - Bell, D.K. (1982): Root diseases induced in corn by Rhizoctonia solani and Rhizoctonia zeae. Phytopathology 72, 86- 91.

Sváb, J. (1981): Biometrical Methods in Research Work. Mezőgazdasági Kiadó, Budapest (in Hungarian).

Vajna, L. - Oros, G. (2005): First Report of Rhizoctonia zeae in Hungary. Plant Pathology 54, 250.

Vajna, L. - Oros, G. (2005): Turfgrass Blight in Hungary. The Role of Rhizoctonia solani and R. zeae in the Disease Development. Plant Protection 59, 149-157. [in Hungarian]

Voorhees, R.K. (1934): Sclerotial Rot of Corn Caused by Rhizoctonia zeae, n. sp. Phytopathology 24, 1290-1303.

Webb, K.M. - Harveson, R.M. - West, M.S. (2015): Evaluation of Rhizoctonia zeae as a potential biological control option for fungal root diseases of sugar beet. Annals of Applied Biology 167, 75-89.

Yamauchi, R.A. - Carling, R. - Kageyama, D.E. - Hyakumachi, K.M. (2002): Differentiation of three varieties of Rhizoctonia circinata var. circinata, var. oryzae and var. zeae on the basis of cellular fatty acid composition. Journal of Phytopathology 150, 1-5. 